\title{
Drug use in pregnancy among parous Scandinavian women
}

\author{
H. Nordeng ${ }^{1}$, A. Eskild ${ }^{2}$, B.-I. Nesheim ${ }^{2}$ and G. Jacobsen ${ }^{3}$ \\ ${ }^{I}$ Department of Pharmacotherapeutics, University of Oslo, Oslo, Norway \\ ${ }^{2}$ Department of Obstetrics, Ullevål University Hospital, Oslo, Norway \\ ${ }^{3}$ Department of Community Medicine and General Practice, Norwegian University of Science and Technology, \\ Trondheim, Norway
}

Corresponding author: H. Nordeng, Department of Pharmacotherapeutics, University of Oslo, P.O. Box 1065 Blindern, NO-0316 Oslo, Norway Telephone: +4722119009 Telefax: +4722119013 E-mail: h.m.e.nordeng@farmasi.uio.no

\begin{abstract}
SUMMARY
The aim of the present study was to investigate the prevalence of drug use in 1945 parous pregnant Scandinavian women, to determine the most common drug categories, and to describe changes in drug use throughout pregnancy. The women were interviewed about drug use by a specially trained midwife at five different occasions during pregnancy: at gestational week 17, 25, 33, 37, and on admission for delivery at three Scandinavian study sites (Trondheim, Bergen and Uppsala). When excluding vitamins and iron supplementation, 1086 (56\%) women reported at least one episode of drug use during pregnancy, with an average of 2.6 episodes among the women reporting drug use. Four percent of the women accounted for $18 \%$ of the episodes of drug use. Systemic anti-infectives (15\%), respiratory drugs (12\%), gastrointestinal drugs (11\%) and analgesics $(11 \%)$ were the most widely used drugs among all the pregnant women. The number of women using drugs increased throughout pregnancy.
\end{abstract}

\section{NORSK SAMMENDRAG}

Hensikt med studien var å undersøke forekomsten av legemiddelbruk hos 1945 annen- eller tredjegangs fødende skandinaviske kvinner, å beskrive hvilke legemiddelgrupper som ble hyppigst brukt, og å beskrive hvordan legemiddelbruken forandrer seg i løpet av svangerskapet. Kvinnene ble intervjuet av en spesialopplært jordmor ved fem tidspunkt under svangerskapet: ved gestasjonsuke 17, 25, 33, 37 og ved innleggelse før fødselen på tre skandinaviske studiesteder (Trondheim, Bergen and Uppsala). Når jern- og vitamintilskudd ekskluderes, hadde $1086(56 \%)$ av de gravide minst en episode av legemiddelbruk under svangerskapet, med et gjennomsnitt på 2,6 episoder blant kvinnene som rapporterte legemiddelbruk. Fire prosent av de gravide stod for $18 \%$ av episodene med legemiddelbruk. Systemiske antiinfektiva (15\%), legemidler med virkning på respirasjonssystemet $(12 \%)$, gastrointestinale legemidler (11\%) og analgetika (11\%) var de hyppigst brukte legemiddelgruppene. Andel gravide som rapporterte legemiddelbruk økte i løpet av svangerskapet.

\section{INTRODUCTION}

Total avoidance of pharmacological treatment in pregnancy is unrealistic and may be dangerous. In order to gain knowledge on factors influencing pregnant women's drug use and possible teratogenic drug effects, pharmacoepidemiological studies are necessary. In addition, by studying how drugs are used in pregnancy, to what extent and by whom, misuse and misconception can be intercepted.

Most pharmacoepidemiological studies in pregnant women have been performed outside Scandinavia. These studies have shown great variety in the prevalence of drug use between and within countries (1-10). A recently published French study showed that $99 \%$ of the pregnant women received prescription for at least one drug during pregnancy with an average of 13.6 drugs per women (11). Data on drug use in pregnancy from Scandinavian studies are summarised in Table 1. Four of these studies were conducted in Sweden between 1963 and 1980 and included a total of approximately 9000 pregnant women. In these studies, $79 \%$ to $93 \%$ of the women used drugs during pregnancy including iron and vitamin supplementation (1-4). A prescription based study among primiparous Danish women, showed that $44 \%$ of the women were prescribed at least one drug during pregnancy. Antibiotics $(29 \%)$ and gynaecological drugs $(13 \%)$ were the most commonly used drugs during pregnancy (7).

Variations between countries in drug use were found in the Drug Utilisation in Pregnancy (DUP) study that included nearly 15,000 pregnant women 
Table 1. Overview of Scandinavian pharmacoepidemiological studies of drug use in pregnancy.

\begin{tabular}{|c|c|c|c|c|c|c|c|c|}
\hline Ref. & Place & Period & $\begin{array}{l}\text { Number of } \\
\text { women }\end{array}$ & $\begin{array}{l}\text { Drug history } \\
\text { obtained }\end{array}$ & $\begin{array}{l}\text { Period of } \\
\text { pregnancy }\end{array}$ & $\begin{array}{l}\text { Percent of pregnant } \\
\text { women talking drugs }\end{array}$ & $\begin{array}{l}\text { Mean number } \\
\text { of drugs taken }\end{array}$ & Most commonly used drugs* \\
\hline 2 & $\begin{array}{l}22 \text { countries } \\
\text { Norway } \\
\text { Sweden } \\
\text { Denmark } \\
\text { Finland }\end{array}$ & $1987-88$ & $\begin{array}{c}14778 \\
(n=482) \\
(n=213) \\
(n=310) \\
(n=180)\end{array}$ & Interview & $\begin{array}{l}\text { Whole } \\
\text { pregnancy }\end{array}$ & 86 & 2.9 & $\begin{array}{l}\text { Analgesic/antipyretic/anti- } \\
\text { inflammatory drugs (17\%) } \\
\text { Anti-infectives }(17 \%)\end{array}$ \\
\hline 3 & $\begin{array}{l}\text { Malmö, } \\
\text { Sweden }\end{array}$ & $1963-65$ & 5678 & Interview & $\begin{array}{l}\text { Whole } \\
\text { pregnancy }\end{array}$ & $>80$ & 5.4 & $\begin{array}{l}\text { Analgesic }(27 \%) \\
\text { Anti-infectives (7\%) } \\
\text { Antihistamines (14\%) }\end{array}$ \\
\hline 4 & Sweden & $1973-74$ & 464 & Interview & $\begin{array}{l}\text { First } \\
\text { trimester }\end{array}$ & $79(74)^{*}$ & - & Analgesics (28\%) \\
\hline 5 & $\begin{array}{l}\text { County of } \\
\text { Jämtland, } \\
\text { Sweden }\end{array}$ & $1971-72$ & 341 & Medical files & $\begin{array}{l}\text { Whole } \\
\text { pregnancy }\end{array}$ & 87 & 3.1 & $\begin{array}{l}\text { Analgesic }(6 \%) \\
\text { Anti-infectives }(19 \%) \\
\text { Antihistamines }(9 \%)\end{array}$ \\
\hline 6 & $\begin{array}{l}\text { Malmö, } \\
\text { Sweden }\end{array}$ & $1979-80$ & 2436 & Interview & $\begin{array}{l}\text { First } 17 \\
\text { weeks }\end{array}$ & $93(74)^{*}$ & - & $\begin{array}{l}\text { Analgesics }(61 \%) \\
\text { Antihistamines }(13 \%) \\
\text { Antibiotics }(11 \%)\end{array}$ \\
\hline 7 & $\begin{array}{l}\text { Southwestern } \\
\text { Finland }\end{array}$ & $1987-88$ & 5851 & $\begin{array}{l}\text { Medical } \\
\text { records }\end{array}$ & $\begin{array}{l}\text { Whole } \\
\text { pregnancy }\end{array}$ & - & - & Analgetics (12\%) \\
\hline 8 & Denmark & $1991-96$ & 16001 & $\begin{array}{l}\text { Prescription } \\
\text { database }\end{array}$ & $\begin{array}{l}\text { Whole } \\
\text { pregnancy }\end{array}$ & 44 & 2.6 & $\begin{array}{l}\text { Antibiotics }(29 \%) \\
\text { Gynaecological drugs (13\%) }\end{array}$ \\
\hline
\end{tabular}

*Disregarding iron and vitamin supplementation

from 22 countries. Women in Norway (32\%) and Sweden $(45 \%)$ had considerably higher use of analgesic/ antipyretics than the total study population of pregnant women (14\%) (6).

In addition to cultural differences, the differences in methodology give rise to differences in the results. Studies based on prescription data do not include overthe-counter (OTC) drugs, like mild analgesics. As medical records in pregnancy often have incomplete drug registration, studies that use this data source may be underestimating the prevalence of drug use. Studies based on retrospective interview may inherit recall bias. Few studies have investigated changes in drug use during pregnancy.

The aim of the present study was to investigate the prevalence of drug use in parous pregnant Scandinavian women, to determine the most common drug categories, and to describe changes in drug use throughout pregnancy.

\section{MATERIAL AND METHOD}

\section{Study population}

The data used in this study are derived from the "Successive Small-for-Gestational-Age" (SGA) study, a multicenter study on risk factors for, and impact of being small for gestational age (12).

All pregnant women, expecting their second or third child in one of the three Scandinavian cities Trondheim, Bergen (Norway) or Uppsala (Sweden) between January 1986 and March 1988, were referred to the study by their primary care doctors at their first antenatal visit. The study included women of caucasian origin who spoke one of the Scandinavian languages and had a singleton pregnancy. Of the 6354 referred women, 432 did not fulfil the inclusion criteria and 200 failed to make the first appointment, leaving 5722 women to be included in the study. These women were assigned to one of three groups. First, a 10 percent random sample was drawn $(n=561)$. Among the remaining, only women with increased risk of giving birth to an SGA child were included in the study $(\mathrm{n}=1384)$. The SGA risk criteria were one or more of the following characteristics: a prior lowbirth-weight child, previous stillbirth, chronic disease (essential hypertension, renal- or heart disease), prepregnancy weight $<50 \mathrm{~kg}$ or smoking. Hence, the present study population included 1945 pregnant women.

\section{Population characteristics}

The womens' ages ranged from 18 years to 44 years with a mean age of 29 years (SD 4.5 years). The mean length of gestation was 279 days (SD 15.5 days). In all, $54 \%$ of the women were smoking, and 5\% reported a chronic disease at study inclusion (high blood pressure $2.9 \%$, cardiac diseases $1.0 \%$, diabetes $0.3 \%$ or chronic renal disorder $1.5 \%$ ). The proportion of women with delivery before 37 weeks of pregnancy was $4 \%$. 


\section{Data collection}

Data on drug use were collected by structured interviews. The interviews were performed at five different occasions, i.e. at gestational week 17, 25, 33, 37, and on admission for delivery. The timing of the interviews were chosen to monitor important periods of foetal growth (early and late second and third trimester) and at admission for delivery.

The characteristics of maximum three episodes of drug use could be recorded at each interview.

\section{Variables}

An episode of drug use was defined as use of a prescription or over-the counter (OTC) drug regardless of type, dosage and duration of use. Hence, usage of the same drug on two different occasions was recorded as two episodes of drug use. The drugs were classified by therapeutical classes according to the Anatomic Therapeutic Chemical Classification of Drugs (ATC) (13) and regrouped into different drug categories (Table 2).

\section{Data analysis}

To study changes in drug use during pregnancy, the number of women using drugs during five different time periods was compared: 1) from conception to completed $17^{\text {th }}$ gestational week, 2) from $18^{\text {th }}$ to completed $25^{\text {th }}$ gestational week, 3) from $26^{\text {th }}$ to completed $33^{\text {rd }}$ gestational week, 4) from $34^{\text {th }}$ to completed $37^{\text {th }}$ gestational week and 5) from their last study interview and up to admission for delivery. The time periods chosen reflect the timing of the study interviews. Since the time intervals were of different lengths, the changes in drug use during pregnancy were calculated as percent of women with at least one episode of drug use per pregnancy week per time period. Chi-square statistics were used to test for differences in drug use between each time period. Student's t-test was used to study differences in the mean number of drug use episodes between SGA-risk women and the randomly selected women. The statistical analysis were performed by using Statistical Package for Social Sciences (SPSS), version 9.0.

\section{RESULTS}

\section{Drug use during pregnancy}

During pregnancy, 1679 women $(86 \%)$ reported at least one episode of drug use. Excluding vitamin and iron supplements, 1086 women (56\%) reported at least one episode of drug use, with an average number of 2.6 episodes among the women reporting drug use (Table 3).

The distribution of number of episodes of drug use in pregnancy is presented in figure 1 .
Table 2. Drug categories and Anatomic Therapeutic Chemical (ATC) codes.

\begin{tabular}{|c|c|c|}
\hline $\begin{array}{l}\text { Name of drug } \\
\text { category }\end{array}$ & $\begin{array}{l}\text { ATC } \\
\text { codes }\end{array}$ & Subcategories \\
\hline \multirow[t]{4}{*}{$\begin{array}{l}\text { Gastrointestinal } \\
\text { drugs }\end{array}$} & $\mathrm{A} 02$ & $\begin{array}{l}\text { Antacid, medication against flatulence } \\
\text { and ulcers }\end{array}$ \\
\hline & A03 & Spasmolytica and anticholinergica \\
\hline & A06 & Laxatives \\
\hline & A07 & $\begin{array}{l}\text { Antidiarrhoea and antiseptic and anti- } \\
\text { inflammatory medication of the intestine }\end{array}$ \\
\hline \multirow{4}{*}{$\begin{array}{l}\text { Cardiovascular } \\
\text { drugs }\end{array}$} & $\mathrm{C} 01$ & Heart glycosides \\
\hline & $\mathrm{C} 02$ & Antihypertensiva \\
\hline & $\mathrm{C} 03$ & Diuretics \\
\hline & $\mathrm{C} 07$ & Beta blockers \\
\hline \multirow{2}{*}{$\begin{array}{l}\text { Dermatological } \\
\text { drugs }\end{array}$} & D02 & Dermal softeners and protection \\
\hline & D07 & Corticosteroides for dermal use \\
\hline \multirow{2}{*}{$\begin{array}{l}\text { Urogenital } \\
\text { drugs and } \\
\text { hormones }\end{array}$} & G02 & Other gynaecological medication \\
\hline & G03 & $\begin{array}{l}\text { Sex hormones and ovulation stimulating } \\
\text { medication }\end{array}$ \\
\hline \multirow{3}{*}{$\begin{array}{l}\text { Topical anti- } \\
\text { infectives }\end{array}$} & D01 & Fungicides for dermatological use \\
\hline & D06 & $\begin{array}{l}\text { Dermatological antibiotics and } \\
\text { chemiotherapeutics }\end{array}$ \\
\hline & G01 & $\begin{array}{l}\text { Gynaecological anti-infectives and } \\
\text { antiseptics }\end{array}$ \\
\hline \multirow{4}{*}{$\begin{array}{l}\text { Systemic anti- } \\
\text { infectives }\end{array}$} & $\mathrm{J} 01$ & Antibiotics for systemic use \\
\hline & $\mathrm{J} 02$ & Antimyotics \\
\hline & $\mathrm{J} 03$ & Chemiotherapeutica for systemic use \\
\hline & G04 & Urological antiseptic and anti-infectives \\
\hline \multirow{5}{*}{$\begin{array}{l}\text { CNS drugs } \\
\text { except } \\
\text { analgesics }\end{array}$} & N01 & Anaesthetics \\
\hline & N02 & Anti-migraine drugs \\
\hline & N03 & Antiepileptics \\
\hline & N05 & Psycholeptics \\
\hline & N06 & Other CNS drugs \\
\hline Analgesics & N02 & Narcotics and analgesics/antipyretics \\
\hline \multirow{3}{*}{$\begin{array}{l}\text { Respiratory } \\
\text { drugs except } \\
\text { antihistamines }\end{array}$} & $\mathrm{R} 01$ & Rhinologica \\
\hline & R03 & Broncodilators and respiratory stimulants \\
\hline & R05 & Expectorants and antitussives \\
\hline Antihistamines & R06 & Systemic antihistamines \\
\hline \multirow[t]{6}{*}{ Other drugs } & $\mathrm{B}$ & $\begin{array}{l}\text { Anticoagulantia, antihemoragica and } \\
\text { medicaments against anemia }\end{array}$ \\
\hline & $\mathrm{H}$ & $\begin{array}{l}\text { Systemic corticosteroides and thyroid } \\
\text { medicaments }\end{array}$ \\
\hline & $\mathrm{L}$ & Alkylating medicaments \\
\hline & M & $\begin{array}{l}\text { Anti-inflammatory and anti-rheumatics, } \\
\text { topical medication against pain }\end{array}$ \\
\hline & $\mathrm{P}$ & Other anthelmintics \\
\hline & $\mathrm{S}$ & Eye and ear medicaments \\
\hline
\end{tabular}

Table 3. Use of drugs in pregnancy among 1945 parous Scandinavian women.

\begin{tabular}{lcc}
\hline & $\begin{array}{l}\text { Average number of } \\
\text { episodes of drug used } \\
\text { users (\%) }\end{array}$ & $\begin{array}{l}\text { during pregnancy among } \\
\text { women using drugs }\end{array}$ \\
\hline Total use of drugs & $1679(86.3)$ & 2.9 \\
Use of drugs excluding & & 2.6 \\
vitamins and iron & $1086(55.8)$ & \\
Use of vitamins & $794(40.8)$ & \\
Use of iron & $1259(64.7)$ & \\
\hline
\end{tabular}




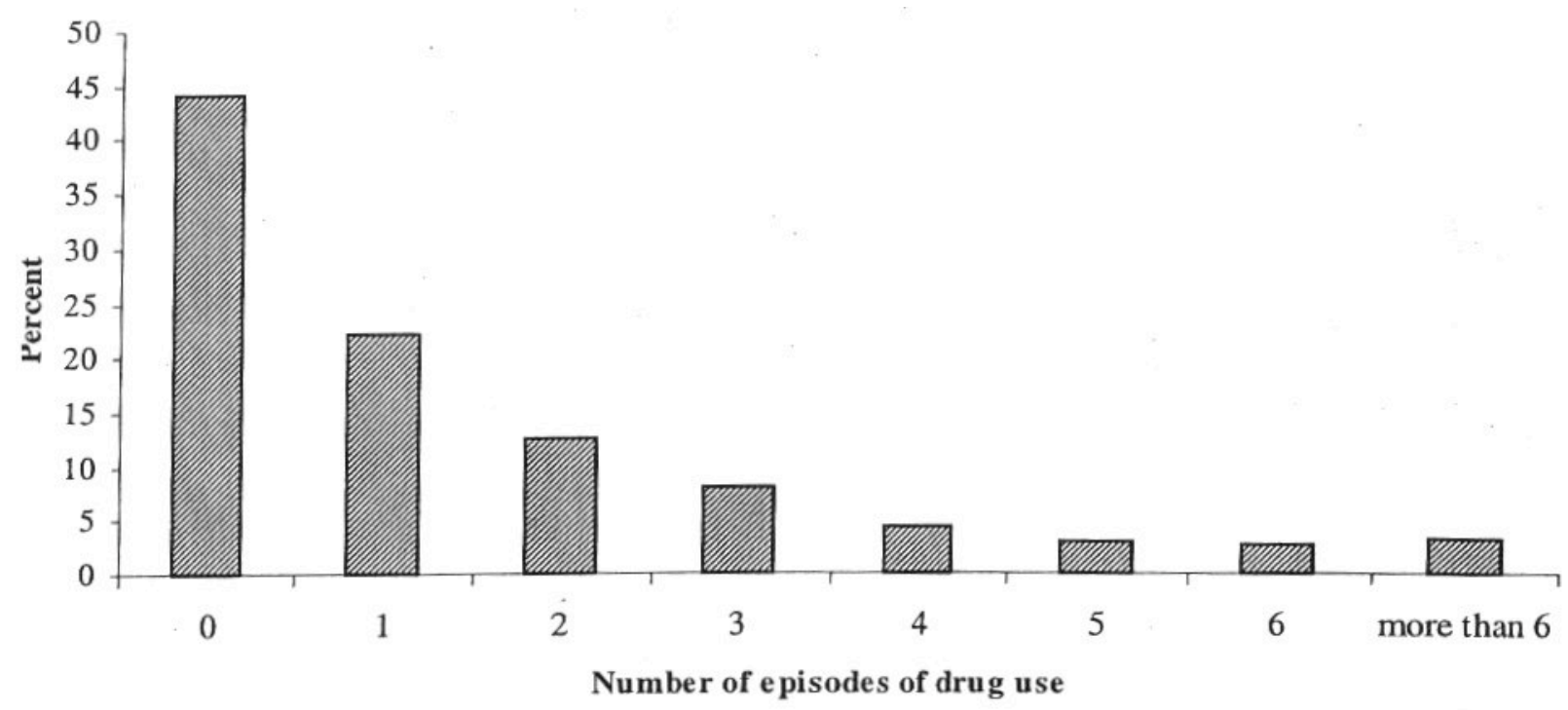

Figure 1. Proportion of women (\%) with different number of episodes of drug use in pregnancy among 1945 parous Scandinavian women.

\section{Drug use according to ATC groups}

In all, 299/1945 women (15\%) reported using systemic anti-infectives and 225/1945 women (12\%) reported using respiratory drugs at least once during pregnancy. Gastrointestinal drugs were used at least once by $219 / 1945$ women $(11 \%)$, and analgesics (both as prescription and over-the-counter analgesia) by $210 / 1945$ women $(11 \%)$ during pregnancy (Figure 2).

Among the women using gastrointestinal drugs, antacids were the most commonly used (117/219, $53 \%$ ). Penicillins were the mostly used systemic antiinfective, used by 110/299 (37\%) of the antibiotic users. Mild analgesics were the most commonly used analgesic $(183 / 210,87 \%)$.

\section{Episodes of drug use among subgroups of women}

Use of drugs at all study interviews

A total of 76/1945 women (4\%) reported at least one episode of drug use at all interviews with an average of seven episodes per woman during pregnancy. The most predominant drugs used by these women were systemic anti-infectives (used by $30 / 76,39 \%$ ), gastrointestinal drugs $(28 / 76,37 \%)$ and analgesics $(25 / 76$, $33 \%$ ). In addition, these women used approximately 7 , 6 , and 9 times more often CNS-, cardiovascular- and dermatological drugs than the total study population, respectively. Chronic disease was significantly more common among women reporting drug use at all interviews than the rest of the study population $(13 \%$ versus $5 \%, \mathrm{p}<0.01$, chi-square test). There was a nonsignificant higher proportions of SGA-risk women among women reporting drug use at all interviews than the rest of the study population $(78 \%$ versus $71 \%$, $\mathrm{p}=0.20$, chi-square test).
Use of drugs among SGA-risk women and randomly selected women

There was no difference in the proportion of women using drugs in pregnancy between SGA-risk women and randomly selected women (56\% versus $57 \%$, $\mathrm{p}=0.63$, chi-square test). Analysed according to pregnancy time period, there was no significant difference in the percentage of SGA-risk women using drugs as compared to the randomly selected population in three of the five time periods: conception to $17^{\text {th }}$ gestational week: $29 \%$ of the SGA-risk women and $29 \%$ of the randomly selected women reported at least one episode of drug use, $\mathrm{p}=0.90,18^{\text {th }}-25^{\text {th }}$ week: $23 \%$ versus $19 \%, p=0.04,26^{\text {th }}-33^{\text {rd }}$ week: $29 \%$ versus $25 \%$, $p=0.11,34^{\text {th }}-37^{\text {th }}$ week: $23 \%$ versus $17 \%, p<0.01$, last interview to delivery: $18 \%$ versus $16 \%, p<0.22$, chisquare test). However, SGA-risk women reported on average a higher number of episodes of drug use among the drug users than the randomly selected women (2.7 episodes of drug use versus 2.3 episodes, $\mathrm{p}<0.01$, Student's t-test).

\section{Changes in drug use during pregnancy}

Figure 3 illustrates the changes in drug use according to time in pregnancy. In all, the proportion of women who used drugs increased throughout pregnancy, from $1.7 \%$ of the population per pregnancy week in the first time period, to $6.4 \%$ per pregnancy week in the last time period $(\mathrm{p}<0.01$, chi-square test).

The proportion of women who used gastrointestinal drugs increased most markedly; from $0.1 \%$ of the women per pregnancy week in the first time period to $1.6 \%$ per pregnancy week in the last $(\mathrm{p}<0.01$, chisquare test) (Figure 3). The use of respiratory drugs 


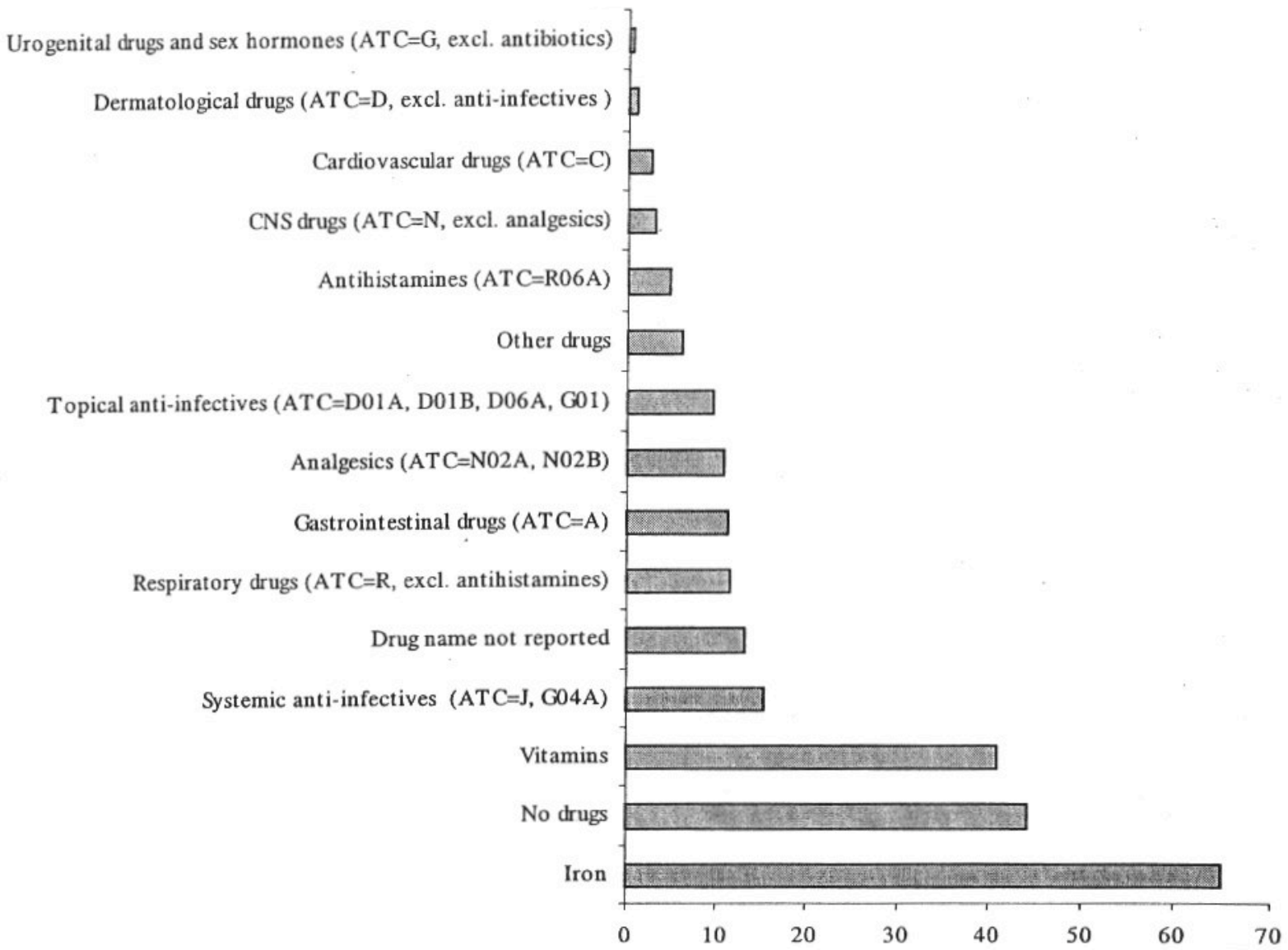

Figure 2. Proportion of women (\%) using different drug categories in pregnancy among 1945 parous Scandinavian women.

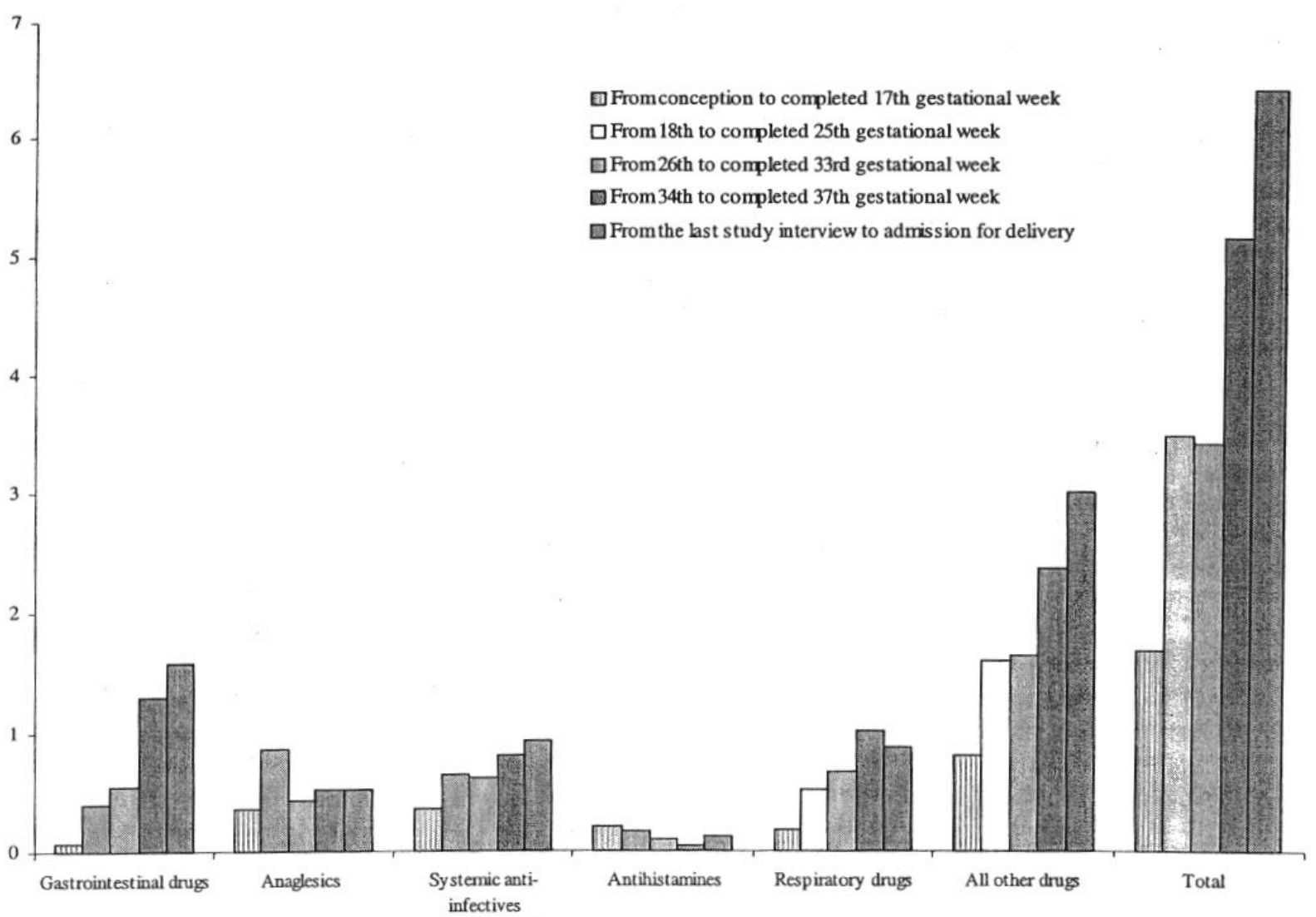

Figure 3. Proportion (\%) of women using drugs per week according to drug category and pregnancy time period among 1945 parous Scandinavian women. 
increased from $0.2 \%$ of the women per pregnancy in the first time period to $1.0 \%$ per pregnancy week from $34^{\text {th }}$ to $37^{\text {th }}$ gestational week $(\mathrm{p}<0.01$, chi-square test $)$ (Figure 3).

\section{DISCUSSION}

In this study, $56 \%$ of the women reported at least one episode of drug use during pregnancy. When including iron and vitamin supplementation the proportion of drug users increased to $86 \%$. Systemic anti-infectives $(15 \%)$, respiratory drugs $(12 \%)$, gastrointestinal drugs $(11 \%)$ and analgesic/antipyretic $(11 \%)$ were the most commonly used drugs. These results are in agreement with results from previous Scandinavian pharmacoepidemiological studies among pregnant women (Table 1).

In our study, four per cent of the women reported at least one episode of drug use at all study interviews. These women accounted for $18 \%$ of all episodes of drug use. Not surprisingly, these women had a higher prevalence of chronic disease before pregnancy. Also, a slightly larger proportion of SGA-risk women belonged to this subgroup. This is likely to be due to chronic disease being a criterion for being in the SGA-risk group.

The proportion of women using drugs increased throughout pregnancy. This increase may be attributed to an increased prevalence of pregnancy related discomfort. Another possible explanation is that physicians may be more reluctant to prescribe drugs during the three first months of pregnancy including the organogenesis period. The increased use of gastrointestinal drugs, especially antacids, throughout pregnancy has also been reported from Denmark (7) and the Netherlands (14). The use of antihistamines was mainly before $18^{\text {th }}$ gestational week, and may suggest that antihistamines are used to alleviate nausea, as nausea is most common early in pregnancy.

This study reports the use of drugs among parous women in 1986-88. Our findings may not reflect today's drug use in pregnancy. However, to our knowledge no previous Scandinavian study has reported changes in drug use during pregnancy. The results may also serve as reference for future studies on drug use in pregnancy. It provides us with more knowledge about the extent of drug use and changing trends in drug use in pregnancy in a Scandinavian population.

About one third of our study population was randomly selected from the general population of parous pregnant women, while the remaining had at least one risk factor of giving birth to a small-for-gestational age (SGA) child. A higher proportion of SGA-risk women reported drug use after the completed $17^{\text {th }}$ gestational week, therefore the percentage of women using drugs in this study may be higher than in the general population. On the other hand, as only three drugs could be registered per interview, the number of episodes of drug use per user in this study might be underreported. Underreporting, however, could only be the case for maximum 43 women $(2 \%)$ who reported use of three drugs at one of the study interviews. Thus, there is no reason to believe that underreporting would have influenced our conclusions.

In this population more than half of the women smoked at study entry. Since smoking has been associated with drug use in other studies, the estimated prevalence of drug use in our study may be higher than the general population of pregnant women $(15,16)$. There was, however, no difference in drug use between smokers and non-smokers in our study.

The fact that none of the women were pregnant for the first time, may effect the way they use drugs, though several studies have not shown parity to be a factor related to drug use $(15,16)$.

\section{CONCLUSION}

The majority of pregnant women in this study reported at least one episode of drug use in pregnancy. The number of episodes of drug use, however, was low, but increasing throughout pregnancy. Four percent of pregnant women accounted for $18 \%$ the episodes of drug use. Few drug utilisation studies have been conducted in Norway, and our results may be useful as a comparison for future studies.

\section{REFERENCES}

1. Bonati M, Bortolus R, Marchetti F, Romero M, Tognoni G. Drug use in pregnancy: an overview of epidemiological (drug utilisation) studies. Eur J Clin Pharmacol 1990; 38: 325-8.

2. Collaborative group on drug use in pregnancy (C.G.D.U.P.). Medication during pregnancy: an intercontinental cooperative study. Int J Gynecol Obstet 1992; 39: 185-96.

3. Kullander S, Kallen B. A prospective study of drugs and pregnancy. I. Psychopharmaca. Acta Obstet Gynecol Scand 1976; 55: 25-33.

4. Boethius G. Recording of drug prescriptions in the county of Jamtland, Sweden. II. Drug exposure of pregnant women in relation to course and outcome of pregnancy. Eur J Clin Pharmacol 1977; 12: 37-43. 
5. Kullander S, Kallen B, Sandahl B. Exposure to drugs and other possibly harmful factors during the first trimester of pregnancy. Comparison of two prospective studies performed in Sweden 10 years apart. Acta Obstet Gynecol Scand 1976; 55: 395-405.

6. Sandahl B. A prospective study of drug use, smoking and contraceptives during early pregnancy. Acta Obstet Gynecol Scand 1985; 64: 381-6.

7. Heikkila AM, Erkkola RU, Nummi SE. Use of medication during pregnancy - a prospective cohort study on use and policy of prescribing. Ann Chir Gynaecol Suppl 1994; 208: 80-3.

8. Olesen C, Steffensen FH, Nielsen GL, de Jong-van den Berg L, Olsen J, Sorensen HT. Drug use in first pregnancy and lactation: a population-based survey among Danish women. The EUROMAP group. Eur $J$ Clin Pharmacol 1999; 55: 139-44.

9. De Vigan C, De Walle HE, Cordier S, Goujard J, Knill-Jones R, Ayme S, Calzolari E, Bianchi F. Therapeutic drug use during pregnancy: a comparison in four European countries. OECM Working Group. Occupational Exposures and Congenital Anomalies. J Clin Epidemiol 1999; 52: 977-82.

10. Matheson I. Drug use in pregnancy. En WHO-studie. Delrapport 1. Februar 1989.

11. Lacroix I, Damase-Michel C, Lapeyre-Mestre M, Montastruc JL. Prescription of drugs during pregnancy in France. Lancet 2000; 356: 1735-6.

12. Bakketeig L, Jacobsen G, Hoffman HJ, Lindmark G, Bergsjø P, Molne K, Rødsten J. Pre-pregnancy risk factors of small- for-gestational age births among parous women in Scandinavia. Acta Obstet Gynecol Scand 1993; 72: 273-9.

13. Guidelines for ATC classification and DDD assignment, WHO Collaborating Centre for Drug Statistics Methodology, 1996.

14. De Jong-van den Berg LT, Van den Berg PB, Haaijer-Ruskamp FM, Dukes MN, Wesseling H. Investigating drug use in pregnancy. Methodological problems and perspectives. Pharm Weekbl (Sci) 1991; 13: 32-8.

15. Bonassi S, Magnani M, Calvi A, Repetto E, Puglisi P, Pantarotto F, Lazzaroni F. Factors related to drug consumption during pregnancy. Acta Obstet Gynecol Scand 1993; 73: 535-40.

16. Buitendijk S, Bracken MB. Medication in early pregnancy: prevalence of use and relationship to maternal characteristics. Am J Obstet Gynecol 1991; 165: 33-40. 